\title{
Ocular repercussions of suspected abusive head trauma
}

\section{Repercusiones oculares ante la sospecha de trauma craneal abusivo}

\author{
Luis P. Orozco-Gómez ${ }^{1 *}$, Julio Martínez-Almada², Luis G. Moreno-Ferreyra³ ${ }^{3}$ Leonor Hernández-Salazar², \\ Andrés Orozco-Mogue/4, Alberto Dávila-Bárcena ${ }^{5}$, and Juan C. Medina-Díaz ${ }^{6}$ \\ ${ }^{1}$ Department of Ophthalmology, Centro Médico Nacional 20 de Noviembre, Instituto de Seguridad y Servicios Sociales de los Trabajadores del \\ Estado (ISSSTE), Mexico City; ${ }^{2}$ Department of Vitreous and Retina, Centro Médico Nacional 20 de Noviembre, ISSSTE, Mexico City; ${ }^{3} T 1$ High \\ Specialty Medical Unit, Instituto Mexicano del Seguro Social (IMSS), León, Guanajuato; ${ }^{4}$ General Hospital of La Paz, IMSS, Baja California; \\ ${ }^{5}$ Department of Retina, Hospital Regional General Ignacio Zaragoza, ISSSTE, Mexico City; ${ }^{6}$ Department of Retina, Hospital Mexiquense de la Salud \\ Visual del Estado de México, Naucalpan de Juarez, Estado de México, Mexico
}

\begin{abstract}
Purpose: To determine the ophthalmological findings in a case series of suspected abusive head trauma, as well as its sequels and treatment. Methods: We conducted a retrospective case series of patients under 1 year of age with suspected history of abusive head trauma caused by shaking, direct trauma, or with a clinical presentation of seizures due to encephalopathy, retinal hemorrhage, or any other systemic repercussions suggestive of the shaken baby syndrome. Results: The study included 8 subjects, of which 5 were male (62\%) and 3 female (38\%), with a mean age of 4.12 months ( \pm 2 months). All of them were examined by the ophthalmology department. In 7 cases (87\%), the reason for consultation was seizures. In $57 \%$ of the studied cases, the mother was the person who witnessed the symptoms. Rib, skull, tibia, acromion, and collarbone fractures were radiologically diagnosed on $4(50 \%)$ patients. All patients (100\%) had bilateral vitreoretinal involvement, including intraretinal hemorrhage (100\%), vitreous hemorrhage (36\%), and post-traumatic macular hole (21\%). Vitrectomy was performed in 29\%. Conclusions: The combination of subdural hemorrhage, retinal hemorrhage, and encephalopathy in subjects under 1 year of age is considered indicative of abusive, inflicted, or non-accidental head injury. While the triad cannot confirm the diagnosis of the shaken baby syndrome, these findings are highly suggestive especially due to the lack of other explanations consistent with the clinical findings. It is highly disputable whether this diagnostic triad can be used as a confirmatory tool for an abusive direct trauma, or both, and the legal consequences may be unsuspected.
\end{abstract}

Key words: Brain damage. Cerebral hemorrhage. Child abuse. Retinopathy. Cranial trauma.

\section{Resumen}

Objetivo: Mostrar los hallazgos oculares de una serie de casos con sospecha de trauma craneal abusivo, su tratamiento y las posibles secuelas. Método: Estudio retrospectivo, serie de casos de pacientes menores de edad con sospecha de trauma craneal abusivo que presentaron crisis convulsivas por encefalopatía, hemorragias intrarretinianas y otras alteraciones sistémicas sugestivas de síndrome del niño sacudido. Resultados: Se incluyeron 8 pacientes, de los cuales 3 (38\%) eran del sexo femenino y 5 (62\%) del sexo masculino. En todos ellos, el servicio de oftalmología acudió como interconsul-

\section{Correspondence:}

*Luis P. Orozco-Gómez

San Francisco, 1626-1605

Col. del Valle, Del. Alcaldía Benito Juárez

Date of reception: 24-09-2019

Date of acceptance: $22-08-2020$

.

E-mail: Ip.orozco@issste.gob.mx

DOI: 10.24875/RMOE.M20000142
Available online: 11-01-2021 Rev Mex Oftalmol (Eng). 2021;95(1):20-26 www.rmo.com.mx 2604-1731/@ 2020 Sociedad Mexicana de Oftalmología. Published by Permanyer. This is an open access article under the CC BY-NC-ND license (http://creativecommons.org/licenses/by-nc-nd/4.0/). 
tante. El motivo de consulta fue por crisis convulsivas en 7 (87\%) casos. La edad media de presentación fue de 4.12 meses ( \pm 2 meses). La persona que presenció los síntomas del infante fue la madre en el $57 \%$ de los casos. Cuatro de los pacientes (50\%) presentaron fracturas (costales, craneales, tibiales, acromiales y claviculares), todas ellas diagnosticadas por estudios radiológicos. El 100\% de los pacientes sufrieron lesiones intraoculares bilaterales: hemorragias intrarretinianas (100\%), hemorragia vítrea (36\%) y agujero macular postraumático (21\%). El 29\% requirió vitrectomía. Conclusiones: La observación de hemorragia subdural, hemorragia retiniana y encefalopatía se considera indicador de sacudida o maltrato de bebés, habitualmente menores de 1 año. El hallazgo de la tríada no hace el diagnóstico, pero es altamente sugestivo de este, en gran parte por la ausencia de otras explicaciones congruentes con los hallazgos clínicos. La base científica para la afirmación de que las lesiones son consecuencia de una violenta sacudida intencionada es altamente discutible y las repercusiones legales pueden tener consecuencias insospechadas.

Palabras clave: Daño encefálico. Hemorragia cerebral. Maltrato al niño. Retinopatía. Traumatismo craneocerebral.

\section{Introduction}

The shaken baby syndrome has traditionally been defined as a group of injuries resulting from a sudden and repetitive flexion-extension movement of the head and neck, caused in a child generally $<2$ years old, who is held by the trunk by another person who shakes him/her violently. This movement generates acceleration and deceleration of the head that favors the development of intraretinal hemorrhages, intracranial hemorrhages, hidden fractures, bruises on the skin, and even injury in the respiratory center at the level of the medulla oblongata, causing the death of the victim due to respiratory arrest ${ }^{1,2}$. Severe sequelae in survivors are not uncommon.

This pathology is little recognized by the medical personnel responsible for its care, so its incidence is unknown, but it is estimated that there are 1200-1600 cases/year, with a mortality of up to $25 \%{ }^{3}$.

Recently, the nomenclature has tried to be more precise and is being modified to abusive head trauma, acquired brain injury, or shock and impact injury, since the scientific basis for the claim that these injuries are the consequence of a violent intentional shaking is highly arguable ${ }^{4}$. Biomechanical evidence has shown that non-contact shaking would only produce the triad of injuries (subdural hemorrhage, retinal hemorrhage, and encephalopathy), along with other injuries to the neck and spinal cord not typically observed in presumed cases of the shaken baby syndrome. Intraocular lesions are usually vitreoretinal, such as macular holes, vitreous hemorrhages, retinoschisis, retinal detachments (which can be tractional or mixed), and intraretinal hemorrhages, which are usually the most common ${ }^{5,6}$.

Most of the literature in this regard is focused on the pediatric area rather than on the ophthalmology area; the reported global incidence is $17-24 \% 7,8$. In Mexico, its frequency cannot be specified because the diagnosis is not usually established in the hospitals where these children are taken for care, and therefore it is not recorded.

It is thought that the mechanism by which the injuries are generated is a violent shaking of the head, which, when supported by the weak muscles of the neck, allows it to go back and forth uncontrollably. These movements cause hypoxia due to involvement of the respiratory center in the medulla oblongata, edema, and cerebral hemorrhage, as well as retinal hemorrhage of variable location and severity ${ }^{9,10}$. In some cases, posterior vitreous detachment also occurs, which causes macular traction and a macular hole and, later, retinal detachment.

In one-third of cases, the patient may also be whipped against a hard surface, causing fracture of the cranial vault and other bones of the body (shaken baby syndrome and with trauma) ${ }^{11}$.

It has been described that the triggering factor for aggression can be intense and inconsolable crying, constant irritability, or a persistent rejection of the child to food ${ }^{12,13}$. It is very difficult to know who the aggressor was. The information has been obtained during the legal trial against some suspicious people. The aggressor is predominantly male and may be the caregiver who, at the beginning of the extremely serious condition, was with the minor ${ }^{14}$.

The manifestations that usually force parents or caregivers to seek emergency medical attention are the sudden and unexpected presentation of seizures, acute neurological deterioration, or critical cardiorespiratory distress $^{15}$. When there is suspicion of the shaken baby syndrome, the medical group of critical medicine services (emergency and pediatric intensive care), and interconsultant services (the ophthalmology service, among others) are required to consider it when a child, usually under 2 years of age, shows this clinical presentation. 
Next, we review the cases diagnosed and treated at the Centro Médico Nacional 20 de Noviembre del Instituto de Seguridad y Servicios Sociales de los Trabajadores del Estado that allow us to know and specify the diagnosis for their comprehensive care. The objective is to present a case series evaluated in a national medical center with the suspicion of abusive head trauma focused on ophthalmological findings, as well as the treatment offered to these patients and the sequelae of abusive head trauma.

\section{Methods}

We present a case series in which all patients with a presumptive diagnosis of abusive head trauma syndrome were included between January 2010 and December 2018. For this review, abusive head trauma was defined as the presence of seizures coupled with retinal or cerebral hemorrhage, with or without several fractures, having ruled out hematological disorders. Sociodemographic and clinical variables were collected (history, caregivers, clinical presentation at home, clinical presentation and injuries upon admission to the hospital, and clinical evolution). The descriptive analysis of the quantitative variables (average and median) and of the relative and absolute frequencies for the qualitative variables was carried out. The statistical tests that could allow making inferences of association between the clinical variables were not carried out since the sample is small, so they are only described.

\section{Results}

Eight patients were included, of which $3(38 \%)$ were female and $5(62 \%)$ male; the average age was 4.1 months (Table 1). In $100 \%$ of the cases, the ophthalmology service acted as an interconsultant when requested by the pediatric service.

The reason for consulting was seizures in 6 patients (83.3\%). Other symptoms that required going to the hospital were respiratory distress, refusal to eat, persistent inconsolable crying, vomiting, drowsiness, and loss of consciousness (Table 2, Figs. 1 and 4).

The people who witnessed the symptoms and who took the child to the emergency room were highly variable, being the mother in $57 \%$ of the cases (Table 3).

Among the findings on clinical examination, four patients $(50 \%)$ had fractures in different locations: skull fracture in two patients (one in the right parietal region and another in the parieto-occipital region), one patient had fractures in four ribs, one more had a clavicular
Table 1. Age and sex of patients

\begin{tabular}{|l|l|c|}
\hline Patient & Sex & Age (months) \\
\hline 1 & Male & $2 / 12$ \\
\hline 2 & Male & $5 / 12$ \\
\hline 3 & Female & $1 / 12$ \\
\hline 4 & Female & $3 / 12$ \\
\hline 5 & Male & $6 / 12$ \\
\hline 7 & Female & $5 / 12$ \\
\hline 8 & Male & $4 / 12$ \\
\hline
\end{tabular}

Table 2. Clinical features before hospital admission

\begin{tabular}{|l|c|c|}
\hline Feature & Number of cases & $\%$ \\
\hline Seizures & 7 & 87 \\
\hline Irritability & 8 & 100 \\
\hline Shortness of breath & 5 & 71 \\
\hline Food refusal & 8 & 100 \\
\hline Crying & 8 & 100 \\
\hline Vomiting & 3 & 37 \\
\hline Drowsiness & 8 & 100 \\
\hline Loss of consciousness & 2 & 29 \\
\hline
\end{tabular}

fracture, and another one had tibial and acromial fractures, all of them diagnosed by radiological studies (Table 4, Figs. 2 and 3).

Among the ocular findings, all patients suffered bilateral intraocular lesions: $100 \%$ had intraretinal hemorrhages in one or both eyes, $36 \%$ had a subhyaloid hemorrhage, $21 \%$ had a grade IV vitreous hemorrhage, and $21 \%$ had a post-traumatic macular hole (Table 5 , Fig. 5). Twenty-nine percent of the patients required pars plana vitrectomy due to persistent vitreous hemorrhage and traumatic macular hole (Fig. 6).

\section{Discussion}

In this case series, $86 \%$ of the patients had seizures, which is highly suggestive of encephalopathy, $100 \%$ had intraretinal hemorrhages and, among other findings, tibial, rib, acromial, cranial fractures, hematomas, and bites. All these findings in the patients made us suspect a battered-child syndrome. 


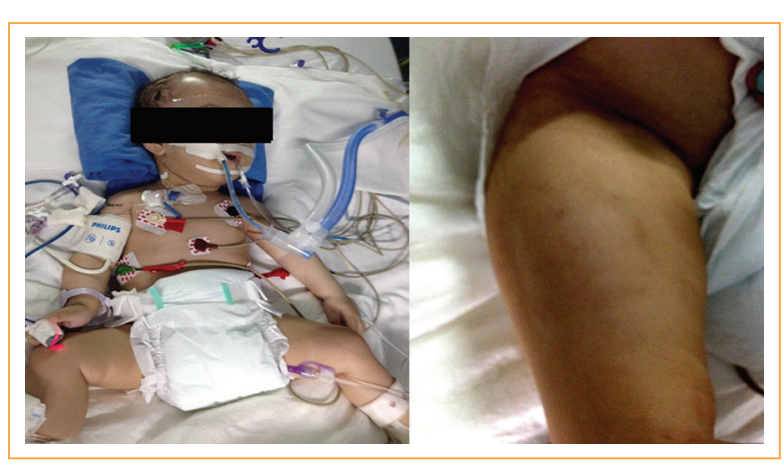

Figure 1. Patient in a barbiturate coma with suspected abusive head trauma; apparent dental arch lesion on the right leg.

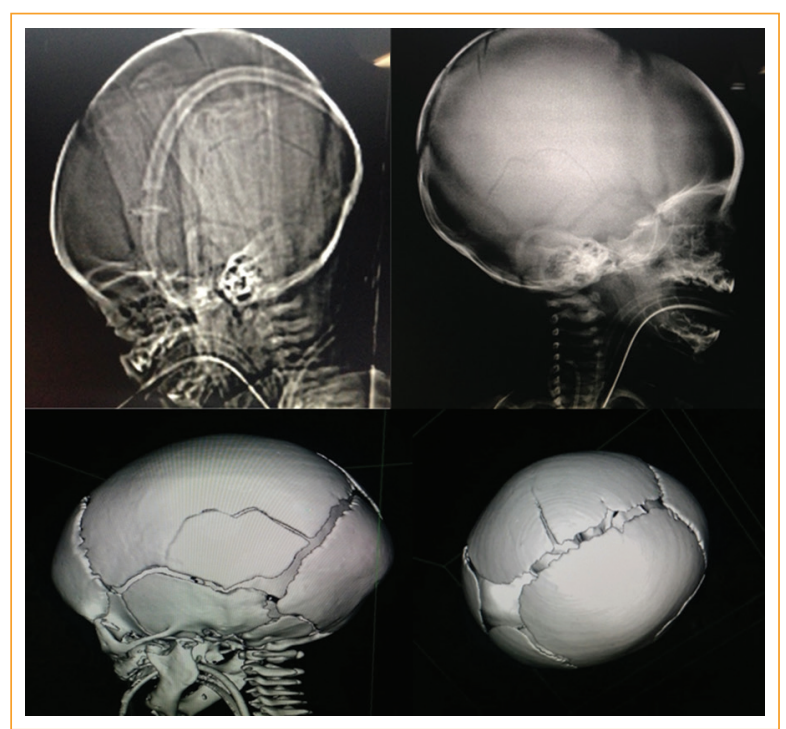

Figure 2. Plain radiography and three-dimensional reconstruction of the skull of one of the patients with a skull fracture.

With the support of the social work department and directed questioning, we found that the symptoms that precipitated the transfer of these children to the hospital were seizures and the people who witnessed the seizures were mothers $(57 \%)$, both parents $(14 \%)$, grandmother (14\%), or a caregiver (14\%).

According to the World Health Organization, child abuse is defined as the abuse and neglect that children under 18 years of age are subjected to, including physical, psychological, or sexual abuse, which damages their health, development or dignity, or puts them at risk of death ${ }^{16}$.

The consequences experienced by a child or adolescent who suffers abuse start from the moment they go
Table 3. People who witnessed the symptoms that brought the child to the emergency room

\begin{tabular}{|l|c|c|}
\hline Relationship & Main caregiver & $\%$ \\
\hline Only mother & 4 & 57 \\
\hline Only father & 0 & 0 \\
\hline Both parents & 2 & 25 \\
\hline Uncles & 0 & 0 \\
\hline Grandparents & 1 & 14 \\
\hline Stepfather & 0 & 0 \\
\hline Domestic caregiver & 1 & 14 \\
\hline
\end{tabular}

Table 4. Other findings

\begin{tabular}{|l|c|c|}
\hline Clinical data & Number of patients & $\%$ \\
\hline Tibial fracture & 1 & 14 \\
\hline Rib fractures & 1 & 14 \\
\hline Cranial fractures & 2 & 29 \\
\hline Bruising & 2 & 29 \\
\hline Bite & 1 & 14 \\
\hline Digital print on leg & 1 & 7 \\
\hline Acromial fracture & 1 & 7 \\
\hline Clavicle fracture & 1 & 7 \\
\hline Intraparenchymal hemorrhages & 8 & 100 \\
\hline
\end{tabular}

Table 5. Ocular findings

\begin{tabular}{|l|c|c|}
\hline & Number of eyes & $\%$ \\
\hline Intraretinal hemorrhage & 16 & 100 \\
\hline Vitreous hemorrhage & 5 & 36 \\
\hline Macular hole & 3 & 21 \\
\hline Retinal detachment & 0 & 0 \\
\hline
\end{tabular}

through that situation and can last for a long time, even years or decades, and even compromise their adult life. In general, the abused child does not meet the development of their growth and development goals, that is, self-esteem, happiness, health, creativity, solidarity, autonomy, and spirituality, in a two-way environment of construction between parents and children. These skills are put at the service of promoting resilience, 


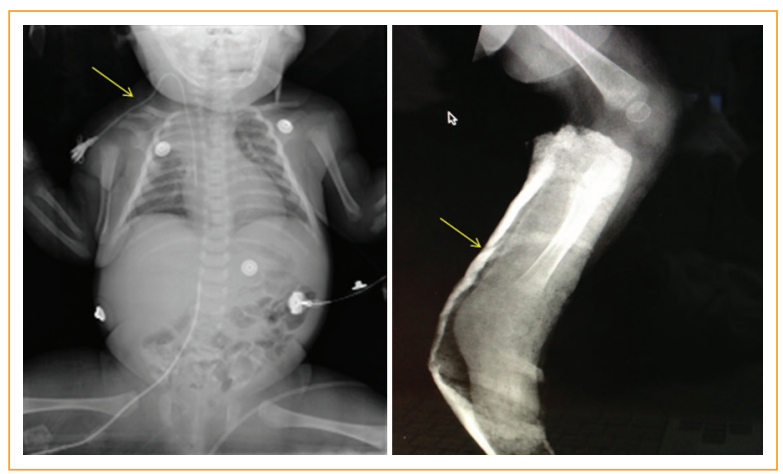

Figure 3. X-rays showing clavicular, acromial, and tibial fractures.

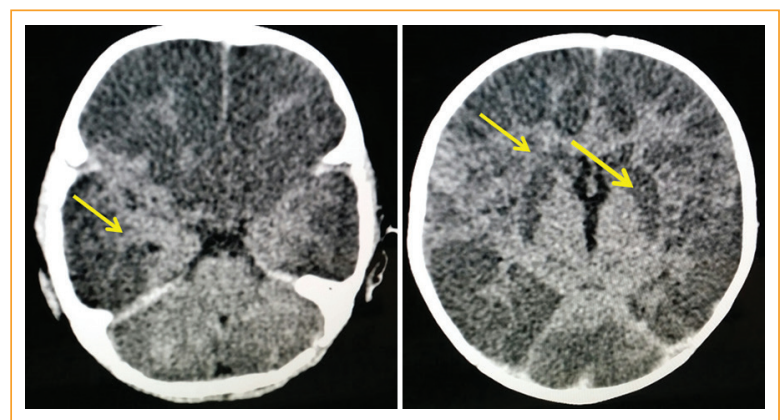

Figure 4. Cerebral edema with more evident rostrocaudal deterioration in the right hemisphere.

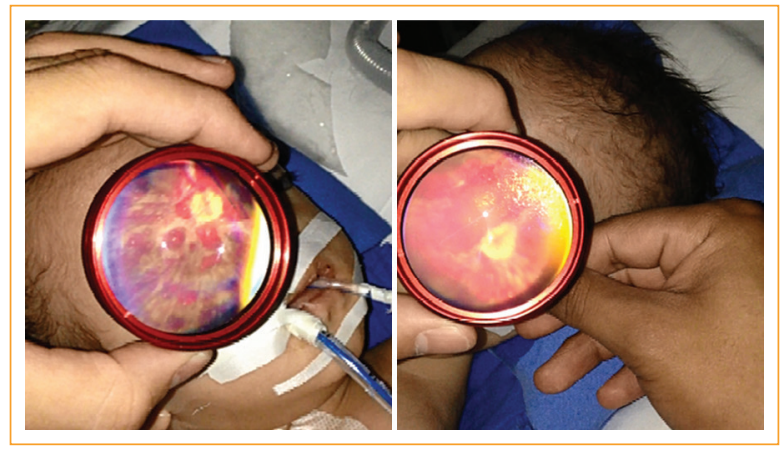

Figure 5. Image obtained with a smartphone of the fundus of both eyes of a patient in the pediatric intensive care unit.

which is the human capacity to succeed in the face of adversity ${ }^{17}$.

There are sentinel injuries that are defined as inflicted minor injuries, which are recognized by the doctor or the parents, which are highly suggestive of abuse. They are common in physically abused children and rare in those

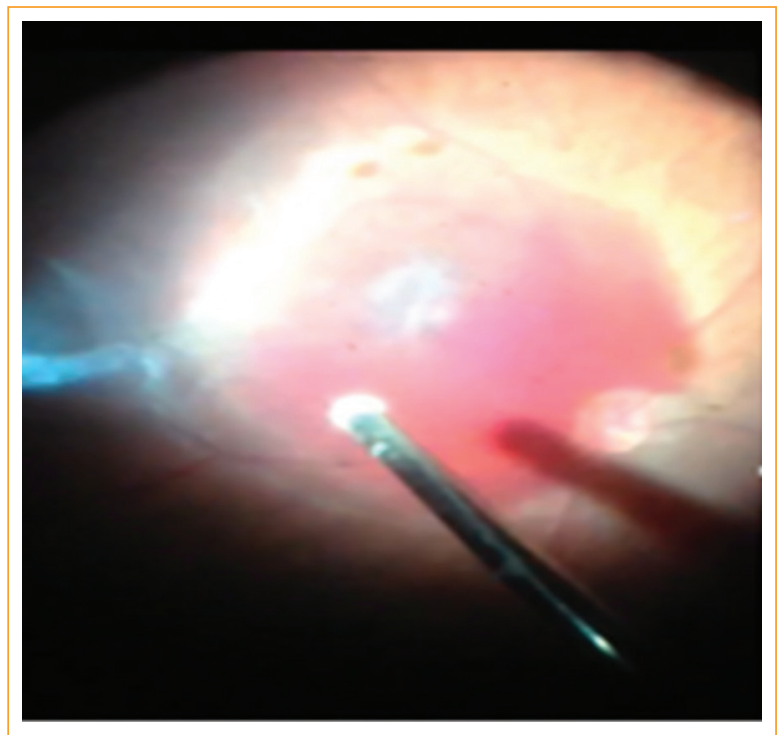

Figure 6. Posterior pole of the right eye during pars plana vitrectomy.

who do not suffer abuse. Its previous presence is identified in up to $25 \%$ of children with physical abuse and one-third of those diagnosed with traumatic brain injury ${ }^{18}$.

Typical indicators of physical abuse, to a lesser or greater degree, are bruises or hematomas in different stages of healing and located on different parts of the body, burns with defined shapes, nose or jaw fractures, or spiral fractures of long bones, sprains or dislocations, wounds or scrapes to the face and back of the limbs and torso, human bite marks, cuts or punctures, and internal injuries (of the skull or brain, symptoms of suffocation.... $)^{19}$.

The presence of subdural hemorrhage, retinal hemorrhage, and encephalopathy is considered an indicator of the shaken baby, usually in children younger than 1 year of age. The finding of the triad does not make the diagnosis, but it is highly suggestive of it, largely due to the absence of other explanations consistent with the clinical findings ${ }^{20}$.

Although the doctors who can propose the diagnosis of the shaken baby syndrome are pediatricians and ophthalmologists due to the consultations requested based on the findings, this is a predominant scientific opinion, but it must be remembered that said syndrome has never been proven as something else than a hypothesis ${ }^{21}$.

Often specialists ignore or disagree with alternative explanations that other specialties may provide or even other points of view within the same specialty. Furthermore, there is a growing number of peer-reviewed scientific articles that challenge the whole concept ${ }^{22}$. 
Notably, the requirement for evidence with a scientific basis is much more rigorous in medical malpractice cases that in family or criminal courts, where believing that something is true seems to be enough evidence to persuade the determinations of the court ${ }^{23}$.

The shaken baby syndrome is increasingly receiving significant criticism, as it lacks scientific validation and forensic rigor. To date, the research carried out raises considerable doubt; furthermore, as long as diagnoses using this term continue to be made, infants are deprived of the investigations necessary to establish the correct cause, treatment and prevention of their recurrence, symptoms, and signs since most diagnoses are not based on an expert opinion but in the description of findings made by pediatricians and ophthalmologists ${ }^{4}$. From a judicial point of view, many considerations will refer to a lengthy investigation, and it can be applied appropriately to abused children. The outcome of a trial will have very serious consequences for those found guilty in a court of having abused children. In Civil Courts, the State may finally impose forced confidential adoptions to sever the ties between children and their parents found guilty in either of the two types of courts, generally sending the children to be guarded by the "Desarrollo Integral de la Familia" institution (in the case of Mexico) ${ }^{24}$.

Any parent who habitually exercises physical or mental violence on the minor under tutelage will face a penalty of between 6 months and 3 years in prison; in addition, if the judge deems it appropriate, he will impose a special disqualification of parental authority from 1 to 5 years, without prejudice to the penalties that may apply for crimes of physical or mental violence.

Leaving aside the assumptions related to parental authority, the person who by any means or procedure causes a person under 12 years of age an injury that undermines their bodily integrity or their physical or mental health, provided that this objectively requires medical or surgical treatment to recover health, may be punished with a prison sentence of 2-5 years ${ }^{25}$.

Children in Mexico and Latin America are unprotected from violence, but not only from crime but mainly from that which occurs inside their homes. In Mexico, only Mexico City, Zacatecas, and Chiapas specifically prohibit corporal punishment in their laws, while Guanajuato and Chiapas prohibit it in their criminal codes. By contrast, the criminal codes of 14 entities provide excuses to injure descendants: either because the aggressor was invaded by a "violent emotion" because he did not do it with intent or because he exercised his "right to correct behaviors."
Article 321 bis of the Federal Criminal Code dictates that no one shall proceed against anyone who negligently (by recklessness) causes injury or homicide to the detriment of an ascendant (parents) or blood descendant in direct line (children), as well as brother, spouse, common-law partner, adopter or adoptee, "unless the perpetrator is under the effect of intoxicating drinks, narcotic drugs, or psychotropics, without medical prescription, or if he does not help the victim"26.

Almost identical paragraphs appear in the codes of Baja California Sur, Chiapas, Morelos, Chihuahua, Nuevo León, Tlaxcala, Zacatecas, Michoacán, Guerrero, and Mexico City.

Article 142 of the Penal Code of Baja California Sur indicates that the punishment for those who "in a state of violent emotion commit the crime of homicide or injury" will be reduced to half, and explains that it is violent emotion when "under the circumstances that triggered the crime, the aggressor's ability to understand what he did and act accordingly is diminished in a considerable and transitory way." It is the same case for Guerrero, Tabasco, the State of Mexico, and Coahuila ${ }^{27}$.

Michoacán, Campeche, and Mexico City reduce twothirds of the penalty for those who commit injuries or homicide "in a state of violent emotion," defined by the Campeche Penal Code as "a motor, circulatory and secretory reaction towards a feeling of great intensity, which produces a transitory psychological disturbance that manifests itself through violent forms of expression, lack of reasoning, discernment, and will."

The Penal Code of Mexico City, finally, defines this emotion as "when the active subject of the crime experiences an intense emotional shock that causes a behavioral disorder, the loss of control of his reflective capacity and the decrease of his inhibitory restraints"28.

While these rules apply to any of the aforementioned family members, children are more vulnerable to injury and less able to defend themselves from their adult relatives, particularly when there is a belief that hurting a child is "necessary" to bring up the child. This belief is institutionalized in the Criminal Codes of the States of Hidalgo and Sonora, where injuries are part of the "right to correct" and, therefore, do not cause penalties.

"Injuries inflicted while exercising the right to correct are not punishable, as long as they are not a habitual or repeated way of exercising this right and do not cause any of the injuries provided for in Article 140 of this Code," that is, that cause damage to health, as refers to article 142 of the Code of Hidalgo ${ }^{29}$. Sonora indicates in its to article 248 that the injuries inflicted by those who exercise parental authority or 
guardianship of minors under their custody "in the exercise of the right to correct, shall not be punishable if they are those included in section I of article 243," that is, "that they do not endanger life and, furthermore, the author shall not abuse that right, correcting cruelly or with unnecessary frequency"30.

In our case series, we made a joint decision of reporting; however, the cases did not progress since the aggression was repeatedly denied by the alleged perpetrators, in such a way that no legal follow-up was achieved.

\section{Conclusions}

Wide dissemination of the subject is required to promote the culture of reporting and monitoring by the multidisciplinary team, institutions, and health professionals involved in the care of children to avoid further attacks on the minor. In our series, the classic diagnosis by interpretation of findings of the battered-child syndrome and the shaken baby syndrome was highly suggestive; however, it has so many aspects and pathophysiologic and legal interpretations that it could not be conclusive, and for this reason, using the terms "abusive head trauma," "acquired brain injury," or "injury by shaking" could be an alternative for nosological classification of child abuse.

\section{Conflicts of interest}

The authors declare no conflicts of interest.

\section{Ethical disclosures}

Protection of human and animal subjects. The authors declare that no experiments were performed on humans or animals for this study.

Confidentiality of data. The authors declare that they have followed the protocols of their work center on the publication of patient data.

Right to privacy and informed consent. The authors have obtained the written informed consent of the patients or subjects mentioned in the article. The corresponding author is in possession of this document.

\section{References}

1. Levin AV. Retinal hemorrhage in abusive head trauma. Pediatrics 2010;126(5):961-70.

2. Kempe $\mathrm{CH}$, Silverman FN, Steele, BF, et al. The battered-child syndrome. JAMA. 1962;181(1):17-24.

3. Casado-Flores J, Díaz-Huertas JA, Martínez González C. Niños maltratados. Madrid: Díaz de Santos; 1997. 388 p.
4. Cohen M, Lynne W, Bache B, Pragnell C. Carta abierta sobre el síndrome del bebé sacudido y los tribunales: una premisa falsa y defectuosa. Rev Electrónica Autops. 2015;13:13-6. Disponible en: http://rea.uninet. edu/index.php/ejautopsy/article/view/80

5. Rufo-Campos M. El síndrome del niño sacudido. Cuad Med Forense. 2006;12:39-45.

6. Simon JW, Zobal-Ratner J. A systematic review of the diagnostic accuracy of ocular signs in pediatric abusive head trauma. Evidence-Based Ophthalmol. 2011;12:26-7.

7. Fernández Couse G, Perea Corral J. Síndrome del maltrato infantil. Rev Cubana Pediatr. 2004;76(3). Disponible en: http://scielo.sld.cu/scielo. php?script=sci_arttext\&pid=S0034-75312004000300009\&lng=es\&nrm=iso\&tlng=en

8. Loredo-Abdalá A, Trejo-Hernández J, Melquiades-Parra I. Síndrome del niño sacudido. Forma extrema del abuso físico infantil. Acta Pediátrica México. 2014;32:177-9.

9. García Pérez J, Díaz Huertas J, Lirio Casero J. El síndrome del niño zarandeado. Bienestar y Protección Infantil. 2003;2:13-23.

10. Hymel KP, Bandak PA, Partington MD, Winston KR. Abusive head trauma? A biomechanics-based approach. Child Maltreat. 1998;3:116-28.

11. Alexander R, Bennett $T$, Smith $W$. Incidence of impact trauma with cranial injuries ascribed to shaking. Am J Dis Child. 1990;144:724-6.

12. Talvik I, Alexander RC, Talvik T. Shaken baby syndrome and a baby's cry. Acta Paediatr Int J Paediatr. 2008;97:782-5.

13. Koen WJ, Squier W. Shaken baby syndrome. Forensic Sci Reform Prot Innocent. 2017;6420:95-136.

14. Loredo-Abdalá A, Casas-Muñoz A, Trejo-Hernández J, Melquiades-Parra I, Martín-Martín V. Síndrome del niño sacudido: cuadro clínico y evolución de 17 casos en el Instituto Nacional de Pediatría. Acta Pediatr Mex. 2015;36:72.

15. Starling SP, Holden JR, Jenny C. Abusive head trauma: the relationship of perpetrators to their victims. Pediatrics. 1995;95:259-62.

16. Organización Mundial de la Salud. Maltrato infantil. 2020. Disponible en: https://www.who.int/es/news-room/fact-sheets/detail/child-maltreatment

17. Caffey $\mathrm{J}$. On the theory and practica of shaking infants. Its potencial residual effects of permanent brain damage and mental retardation. Am J Dis Child. 1972;124:430-1.

18. Porras VR, Pérez V. Síndrome del niño sacudido: la importancia de las hemorragias retineanas y hematomas subdurales en sudiagnóstico. Acta Pediatr Costarric. 2002;16:2.

19. King WJ, MacKay M, Sirnick A. Shaken-baby syndrome in Canada; clinical characteristics and outcomes of hospital cases. CMAJ 2003:168:155-9.

20. Verdú F. En busca de la tríada. Gac. int. cienc. Forense. 2018. N. 27, abril-junio. Disponible en: https://www.uv.es/gicf/1Ed2_Verdu_GICF_27.pdf

21. Rufo M. El síndrome del niño sacudido. Cuad Med Forense. 2006;12:43-4

22. Corchado HS, Loredo-Abdalá A, Pérez Martínez A, Villa RA. El niño maltratado: obstáculos medicos y legales en el diagnóstico y asistencia integral. Bol Med Hosp Infant Mex. 2004;61:412-22.

23. Hymel K, Hall C. Diagnosing pediatric head trauma. Guidance for pediatricians on distinguishing between accidental and inflicted. Pediatrics Annals. 2005;34,358-70.

24. Loredo-Abdalá A, Trejo-Hernández J, Melquíades-Parra I. Síndrome del niño sacudido. Forma extrema del abuso físico infantil. Acta Pediatr Mex. 2011;32:177-9.

25. Código Penal para el Distrito Federal en Materia de Fuero Común, y para toda la República en Materia de Fuero Federal. (Consultado el 2 de agosto de 2020.) Disponible en: https://www.google.com/search?rlz=1C1CHBF_esMX892MX892\&biw=1366\&bih=625\&sxsrf=ALeKk01ZQwLo18Z1cl4g9rb0ymg44nuclw\%3A1596555745466\&ei=4YEpX9uJHliuswWg

26. Código Penal Federal de la Ciudad de México. Cámara de Diputados. H Congreso de la Unión. Título Decimonoveno. Capítulo III. Última reforma publicada DOF 24-01-2020. Disponible en: http:// www.diputados.gob.mx/LeyesBiblio/pdf_mov/Codigo_Penal_Federal.pdf

27. Código Penal de Baja California. H Congreso del Estado de Baja California. Capítulo VI, Lesiones. Última reforma P.O. No. 49, Secc.III, 23 de octubre de 2015. Disponible en: http://www.ordenjuridico.gob.mx/Documentos/Estatal/Baja\%20California/wo80296.pdf

28. Codigo Penal de la Ciudad de Mexico, última reforma publicada en la Gaceta Oficial de la Ciudad de México, el 31 de diciembre de 2018. Libro primero, Disposiciones generales, Título preliminar de los principios y garantías penales, Capítulo III, Reglas comunes para los delitos de homicidio y lesiones (reformado, g.o. 18 de marzo de 2011). Disponible en: https://docs.mexico.justia.com/estatales/hidalgo/codigo-penal-para-el-estado-de- hidalgo.pdf

29. Código Penal para el Estado de Hidalgo, última reforma publicada en el Periodico Oficial del 30 de julio de 2018. Capítulo II, Lesiones. Disponible en: http://www.congresohidalgo.gob.mx/biblioteca_legislativa/Leyes/09Codigo\%20Penal\%20para\%20el\%20Estado\%20de\%20 Hidalgo.pdf

30. Código Penal del Estado de Sonora. Libro primero, Título decimosexto, Delitos contra la vida y la salud. Capítulo I, Lesiones. Disponible en: http:// www.congresoson.gob.mx:81/Content/Doc_leyes/doc_443.pdf 